Article

\title{
The Effect of Coastal City Development on Flood Damage in South Korea
}

\author{
Hyungjun Park ${ }^{1}$, Robert Paterson ${ }^{2}$, Stephen Zigmund ${ }^{2}$, Hyunsuk Shin ${ }^{3}$, Youngsu Jang ${ }^{4}$ and \\ Juchul Jung ${ }^{5, *}$ \\ 1 BK21PLUS, Department of Urban Planning and Engineering, Pusan National University, Busan 46241, Korea; \\ hjpwell@gmail.com \\ 2 Community and Regional Planning Program, School of Architecture, University of Texas at Austin, Austin, \\ TX 78712, USA; rgfp@austin.utexas.edu (R.P.); stephen.zigmund@gmail.com (S.Z.) \\ 3 Department of Civil and Environmental Engineering, Pusan National University, Pusan National University, \\ Busan 46241, Korea; hsshin@pusan.ac.kr \\ 4 Korea GI\&LID Center, Pusan National University, Pusan National University, Busan 46241, Korea; \\ jysone@nate.com \\ 5 Department of Urban Planning and Engineering, Pusan National University, Busan 46241, Korea \\ * Correspondence: jcjung@pusan.ac.kr
}

Received: 22 January 2020; Accepted: 24 February 2020; Published: 1 March 2020

\begin{abstract}
Flood damage continues to be an issue in coastal cities. Impervious areas that contribute to flood damage are increasing due to the continuous development of ports in cities. However, previous research has not explored development in port hinterlands and in the coastal flood risk areas of coastal cities. Therefore, this study analyzed the impact of coastal city development on flood damage in Korea. A panel Tobit analysis was conducted on 58 coastal cities between 2002 and 2018. The results revealed that a $1 \%$ increase in impervious surfaces and one coastal development permit would increase damage costs by $1.29 \%$ and $2 \%$, respectively. The analysis revealed that the increasing development of coastal cities had a significant impact on flood damage. The findings suggest that land-use plans highlight a conflict between port development and safety. This article provides insight that can be used by policy makers to manage risk areas near ports.
\end{abstract}

Keywords: coastal development; urban planning; flood; South Korea; panel Tobit regression

\section{Introduction}

Over the past several decades, increasing development in coastal cities has been highlighted as one of the major factors of flood damage [1]. Not only do typhoons and heavy rains occur frequently [2], also, urban development that leads to unprecedented severe flood damage has increased [3,4]. For urban planning in particular, public resources have been devoted to building public facilities for urban development [1].

Since increases in port trade, ports have played a leading role in coastal city development $[5,6]$. Port policy includes the initiation of programs to provide public facilities and the investment of a considerable amount of resources and energy in response to problems associated with severe floods [7-11]. As a result, programs such as the World Port Initiative have been adopted as mitigation measures against floods [12-14]. In Europe, studies have shown that urban development should be managed to mitigate flood damage [15].

A large volume of literature has been devoted to assessing the relationship between urban development and flood damage [16-19]. However, scholars have concentrated only limited attention on urban development within the context of the paradox that arises when development takes precedence 
over safety in risk areas [20,21]. Whereas some studies have assessed urban development in risk areas [22,23], they may be irrelevant in describing current urban development in coastal cities. Previous studies have not explored the effect of development in coastal cities, though attention has been given to coastal city development and urban development in conjunction with port development.

This study analyzes the relationship between coastal city development and flood damage in South Korea, which has been actively developing ports at 58 coastal cities from 2002 to 2018. Scholars have been concerned about minimizing urban development in risk areas to mitigate floods. If development is not conducted in a risk area, no damage will occur. In light of this, the present study examines the urban development of cities, which is South Korea, focusing on impervious areas and permits to pursue development in risk areas and port hinterlands. This research will contribute to further understanding the significant impact that coastal city development can have on flood damage. The analysis suggests the need for an integrated response by urban development and port authorities in coastal cities where increased risks of floods exist.

\section{Literature Review}

Increased flood damage risks in cities is characterized by increased hazard, vulnerability, and exposure [24]. The likelihood of extreme weather hazard is increasing in coastal cities. Extreme weather has increased in most regions due to climate change. In addition, cities are affected by flood damage, and the manner in which they are affected depends on their individual citizens' physical and economic abilities and the capacity of their communities. For example, elderly populations have difficulty responding to and recovering from damage, because they lack physical and financial resources [25]. The damage also depends on the financial status of communities [26,27]. Development in coastal cities increases exposure to risk, and development increases surface runoff, resulting in more extreme weather damage [1]. Therefore, several scholars in the US and Europe have suggested that a different approach should be considered in urban planning; in particular, a European research project proposed establishing connectivity between various actors, levels, and sectors [15].

Among the factors affecting flood damage, urban development is one that cannot be reversed once it begins. Public facilities that are necessary for development to proceed should be adequately provided. If public facilities such as electricity and gas are not supplied, growth is unlikely to occur. In such a case, Beatley [1] stated that infrastructure should be planned and designed to operate without exposure to risk. Therefore, to reduce flood damage, public facilities should not be located in risk areas.

Development in risk areas should be minimized through links between organizations with different functions in the city [28]. Even though urban planning avoids development in risk areas, port development is inherently close to risk areas; therefore, urban development in risk areas near ports cannot be avoided. This is because ports are accompanied by large-scale public facilities, such as electricity, highway, and water and sewerage infrastructure, which induce urban development. It can lead to adverse effects on the environment and city. According to a study by Ramos [9], the fourth largest port of the United States, Savannah Port (in Georgia), increased the size of container ships after the expansion of the Panama Canal: This costed \$65 million for dredging (32 miles) and widening (from 42 to $47 \mathrm{ft}$ ). Moreover, the emergence of a coalition of logistics companies that operates ships has also led to an increase in logistics and facilities in some cities [29,30]. Therefore, in coastal areas, urbanization expands because of port-related infrastructure. This paradoxical situation is inherent in coastal areas where stable port operations are possible. In short, urban development near ports is likely to occur in coastal flood risk areas.

As coastal city development often proceeds according to port development, flood damage is also an issue in the port sector [15,31], and ports-related mitigation measures are also focused on structural aspects. Although there are international port coalitions and movements, such as the establishment of the World Port Climate Initiative, only 76 of the 365 ports are involved, and most of the measures adopted by these ports focus on technological improvement and development, infrastructure development, and monitoring, which includes Greenport methods [14,32]. 
Continuing development of coastal cities can lead to increasing risks. Burby [20] explained the local government paradox in which growth is prioritized in cities, even in risk areas. This explanation helped to establish and analyze a research model for urban development centering on coastal cities, which bear the brunt of flood damage. Hoyle's model [6] only indicated that the port-city relationship would be reinforced in the interaction. Hoyle did not cover the paradox of development in risk areas. Previous research had limitations to conceptualizing and measuring exposure in coastal cities. Burby's study [20] demonstrated a limitation in dealing with exposure only by population. The variables were not set in consideration of urban development.

To measure exposure in cities, scholars adopted an urban development approach [33,34]. Brody et al. [22], who studied Florida from 1997 to 2001, where floods occur frequently, found that impervious areas and permits to develop wetlands were significant variables that increased damage. Brody et al. [22] argued that policy internalized the adverse effect of development in the planning process, such as development fees for wetland permits. They suggested the need for an urban planning approach alongside exposure factors in risk areas. Kantamaneni et al. [35], who studied Southampton, United Kingdom, which is the location of one of the key port cities in the UK during the 2013-2014 winter, indicated that 38\% of the city's coastline was highly vulnerable. Ha and Jung [23], who studied 104 cities in South Korea from 1995 to 2014, indicated that impervious areas in South Korea were a significant factor for flood damage. However, previous studies had other limitations, including their inability to conceptualize and analyze the development of dangerous areas behind ports where conflicts between development and safety exist.

\section{Research Methods}

\subsection{Research Rationale}

This study established a conceptual model of a coastal city that incorporated the content shown in Figure 1. The conceptual model plots virtual cities (A, B, C, D) over time. This model improves the port-city relationship emphasized by Hoyle [6]. This study presented a model that demonstrated the development that causes flood damage. The paradox of development in risk areas has been established [8], and it was considered in our model. In particular, the conceptual model demonstrates the development of coastal cities over time, especially in risk areas. There are four schematic concepts: port, port hinterland area, city development, and coastal flood risk areas. They reveal that the ports, port hinterlands, and urban development corresponding to the development of coastal cities could occur in coastal flood risk areas. We sought to show that urban development around ports increased in coastal flood risk areas. Over time, permits are provided, and the developments that appear are shown together.

As seen in Figure 1, port areas are hatched and located in Cities B and C. Coastal flood risk areas are shown in blue and exist in Cities A and B. Since the figure examines physical conditions only, it is assumed that there is no change even as time passes. Squares painted in black correspond to urban development and represent buildings and facilities. As time goes by, urban development increases, so the number of squares also increases. Urban development takes place in all four cities. The area behind the port is a dotted rectangle, with the total number of buildings in the dotted line increasing 1.3 times, from 18 to 24 . In other words, as time passes, the number of buildings increases.

This study mainly addresses city development in the port hinterlands and coastal flood risk areas. The number of buildings within the dotted lines that overlap the coastal flood risk areas (the blue area) doubles from six to twelve. This study assumes that flood damage will increase if development is carried out in coastal cities. In addition, if the impermeable area increases with urban development, flood damage will increase. Accordingly, research questions and hypotheses were established to explore whether flood damage would be affected by an increase of urban development permits in risk areas. 


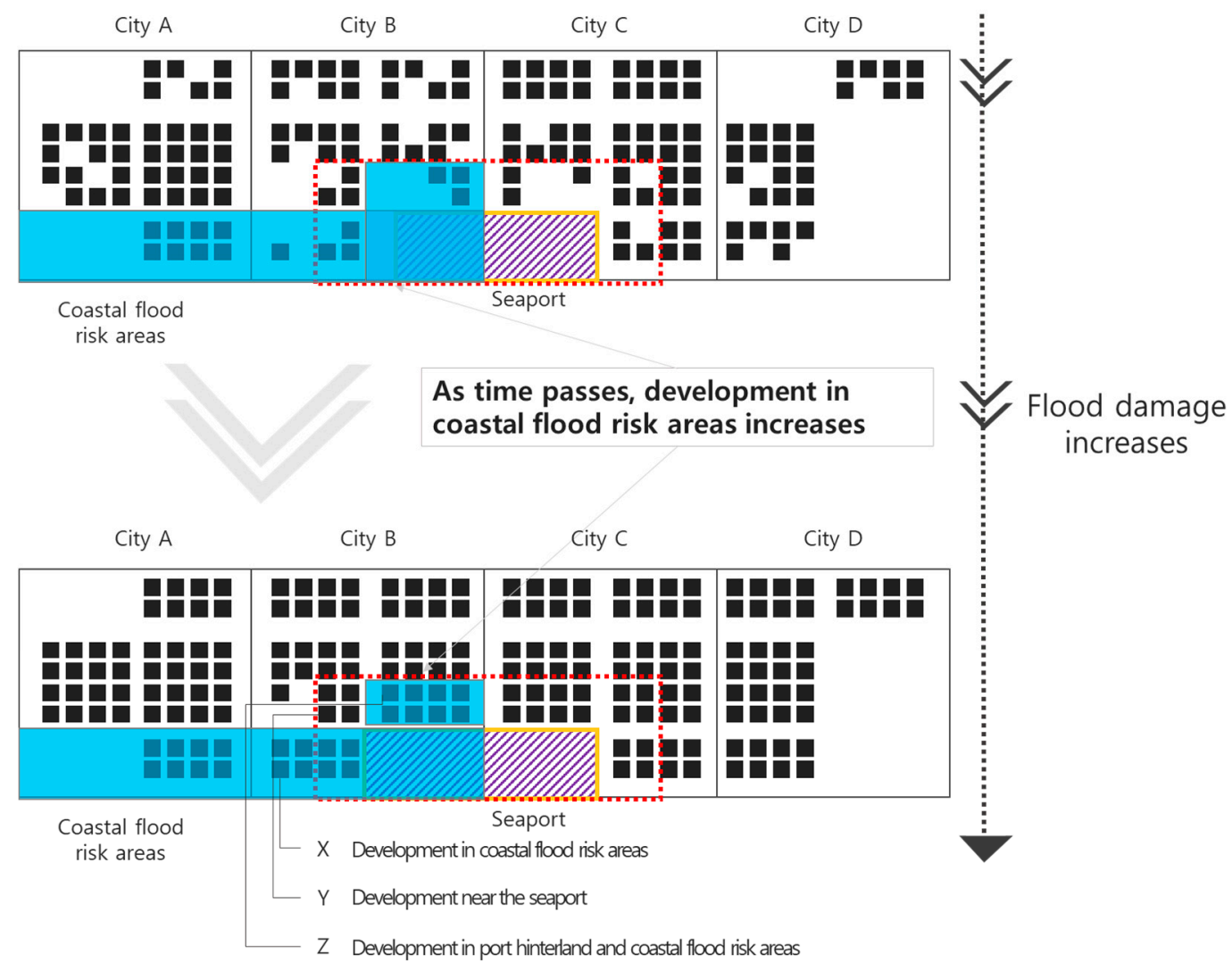

Figure 1. Research model.

\subsection{Research Question and Hypotheses}

This study formulated a research question and hypotheses based on the conceptual model.

Research question: How does coastal city development exacerbate flood damage in coastal cities?

Hypothesis 1: As coastal cities increase their urban development area, flood damage will increase.

Hypothesis 2: As the number of permits for urban development in coastal flood risk areas behind the port increases, flood damage will increase.

This study analyzes how coastal urban development exacerbates flood damage. The first hypothesis states that urban development areas cause flood damage in coastal cities. The study analyzes areas of intensive urban development found in coastal cities. Previous studies have not shown the importance of urban development in plans to reduce flood damage in coastal cities. This study expects to demonstrate that flood damage will increase as urban development area increases in coastal cities. The second hypothesis states that permits for urban development behind ports in coastal flood risk areas will cause flood damage. Previous studies have failed to analyze the variables and effects of development occurring behind ports in coastal flood risk areas.

\subsection{Case Area}

This study explores data for coastal cities in Korea. In Korea, the percentage of impervious areas alone is higher than the domestic average (6.2\%), and the development of coastal areas is higher than that of inland areas [36]. One reason to be wary of coastal urbanization is increasing land cover. Land, roads, and factory sites that correspond to impervious areas of land cover increased by $263.6 \mathrm{~km}^{2}$ from 2007 to 2012 [37]. 
In this study, the unit of analysis is the coastal city. There are 74 cities in Korea, including the coastal cities that are the subjects of this research. The study explored 58 coastal cities in total. The process of selecting coastal cities for the study was as follows: First, 72 cities that need coastal management were selected from the total 74 coastal cities. According to the Coastal Management Act in Korea, erosion control, coastal maintenance, and natural coast management are the key points for coastal management. Two cities in Jeju Island (Jeju-si and Seogwipo-si), which have strong marine characteristics, were excluded, as there was difficulty in obtaining data on flood damage. An additional 14 cities were excluded because there was no coastal flood risk information. As coastal flood is caused by typhoons and heavy rains, coastal flooding projections are mostly available for coastal cities around the West and South Seas. Five cities in Gyeongbuk (Gyeongju-si, Pohang-si, Yeongdeok-gun, Uljin-gun, and Ulleung-gun) and six cities in Gangwon (Gangneung-si, Donghae-si, Sokcho-si, Samcheok-si, Goseong-gun, and Yangyang-gun) do not have coastal inundation forecasts; that is, spatial information that detects the risk of flooding on the coast. A total of 11 cities were therefore excluded from this study. Finally, three cities (Incheon[Ongjin-gun and Ganghwa-gun], Gyungggi[Gimpo-si]), which are located near latitude 38 of South Korea, were also excluded from the coastal flood forecast.

The 58 selected coastal cities in South Korea are located on the coast in the West and South Seas and experience heavy rain and typhoons (Figure 2, Table 1). In South Korea, typhoons and heavy rains are rare in cities located in the East Seas. As a result, coastal flood risk areas are being developed around the West and South Seas. Furthermore, international trade ports are located on the South and West Seas where the Busan port and Gwangyang port are located. This has the advantage of demonstrating the effect of urban development on flood damage in coastal cities.

Table 1. List of coastal cities for the case area.

\begin{tabular}{ll}
\hline \multicolumn{1}{c}{ Region } & \multicolumn{1}{c}{ City } \\
\hline 10 cities in Busan (BS) & Dong-gu, Gangseo-gu, Gijang-gun, Haeundae-gu, Joong-gu, Nam-gu, \\
Saha-gu, Seo-gu, Sooyoung-gu, Youngdo-gu \\
4 cities in Incheon (IC) & Dong-gu, Joong-gu, Namdong-gu, Nam-gu, Seo-gu, Yunsoo-gu \\
4 cities in Ulsan (US) & Book-gu, Dong-gu, Nam-gu, Wooljoo-gun \\
7 cities in Chungnam (CN) & Ansan-si, Hwasung-si, Pyungtaek-si, Siheung-si \\
4 cities in Jeonbook (JB) & Asan-si, Boryung-si, Dangjin-si, Hongsung-gun, Seocheon-gun, Seosan-si, \\
& Baegan-gun \\
& Booan-gun, Gimjae-si, Gochang-gun, Gunsan-si \\
16 cities in Jeonnam (JN) & Haenam-gun, Hampyung-gun, Jangheung-gun, Jindo-gun, Mokpo-si, \\
& Mooan-gun, Shinan-gun, Soonchun-si, Wando-gun, Yeosoo-si, \\
& Youngam-gun, Younggwang-gun \\
7 cities in Gyungnam (GN) & Changwon-si, Geoje-si, Gosung-gun, Hadong-gun, Namhae-gun, \\
& Sacheon-si, Tongyoung-si \\
\hline
\end{tabular}




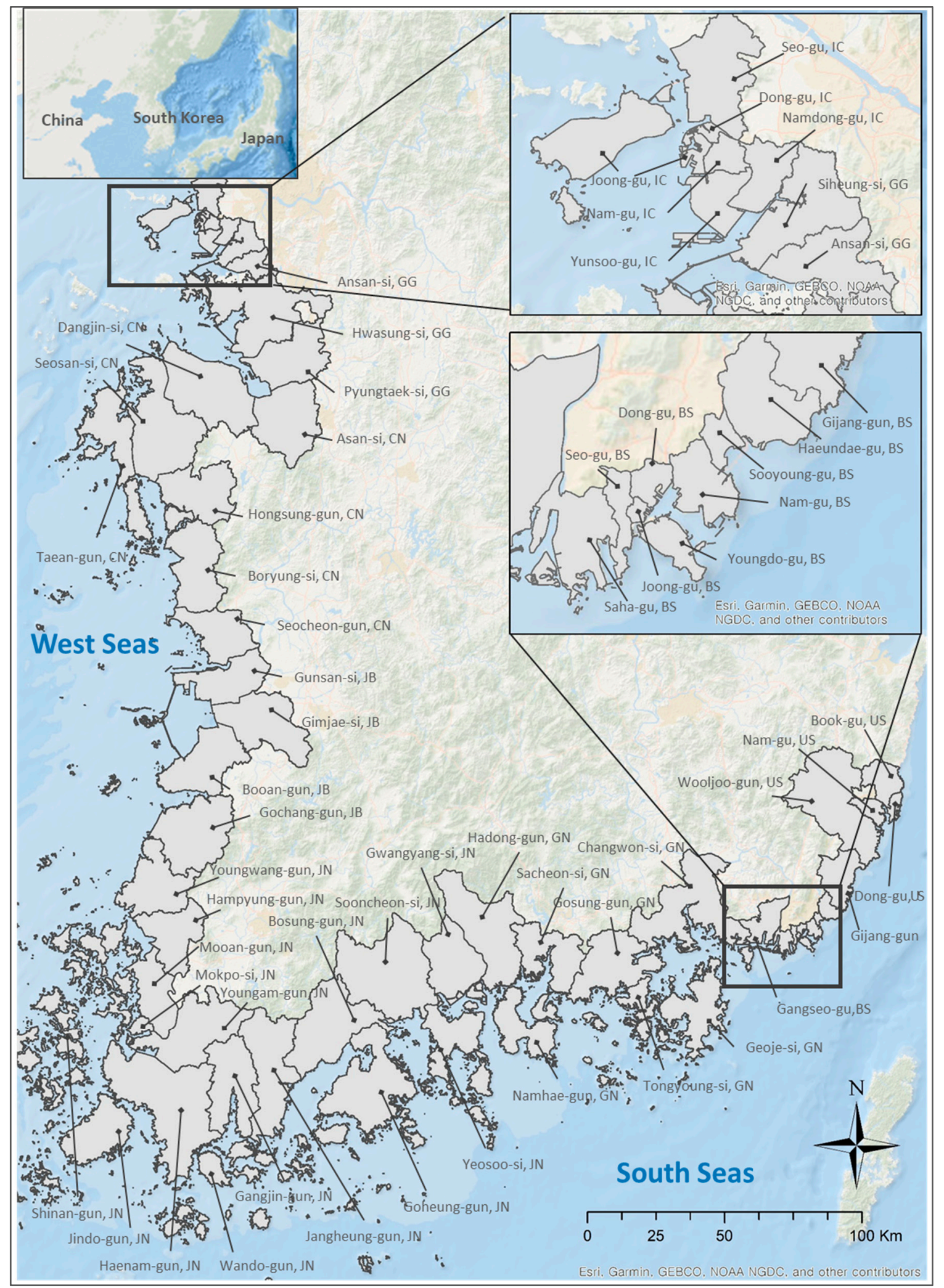

Figure 2. Map of coastal cities for the case area.

\subsection{Data}

To analyze flood damage in coastal cities, this study included an analytical model that considered variables such as climate, vulnerability, and exposure, as shown in Table 2 . The study measured the 
concept of flood damage in coastal cities as variables of heavy rain and typhoon damage. Heavy rain and typhoon damage can be measured according to the annual disaster report published by the Ministry of Interior and Safety (MOIS) [38]. Floods and storms are the most common types of damage in natural disasters [39].

Climate-related factors were treated as control variables. The factors related to climate consisted of daily precipitation and coastal location characteristics. The greater the precipitation, the greater the flood damage. Rainfall data have been available since 1998 from the Korean Climate Data Service System (KCDSS) [40]. Precipitation by hour was provided for each point. After calculating the precipitation for 24 hours, coastal cities with multiple observation points were averaged. In addition, the study analyzed the characteristics of coastal cities based on meteorological factors. This was because the South Sea coast was classified as vulnerable to typhoons [37]. We included one city each from Haenam-gun, Jeonnam, and Haeundae-gu, Busan, located on the south coast of South Korea.

The second control variable, vulnerability, consisted of the population that was over 65 years old and local taxes. A population aged 65 and over was selected as a variable because it is a physically and economically vulnerable population. People aged 65 and older suffer more damage due to physical reasons, and the larger a population of this age, the more damage the city will experience [25]. This study collected data regarding the number of registered residents and the percentage of this population from the Korean Statistical Information System (KOSIS) [41]. Local taxes can highlight the community's economic capacity to respond to disaster [26]. Since no data were available for gross domestic product, this study used information regarding the city's local taxes from KOSIS [42]. The greater the local taxes, the more likely the establishment and implementation of disaster prevention programs.

Variables related to exposure were set as independent variables. The first was impervious areas of coastal cities. In a preceding study, land area was measured according to the time range of the data from KOSIS [43], with building land, factory sites, and roads used as variables for impervious areas. The second independent variable was city development permits in port hinterlands and in coastal flood risk areas. To identify port hinterlands and coastal flood risk areas, we overlaid the two areas over each other. Using port area, we created a port hinterland area. This geographical range was based on the Korean announcement of plans to foster development in areas within $1.5 \mathrm{~km}$ of the port hinterland, and it set a specific range for behind the port. For coastal flood risk areas, spatial information based on coastal inundation forecasts developed by the National Maritime Research Institute was used. After overlaying port hinterlands and coastal flood risk areas, we identified whether or not permits were proceeded with. Permit data have been available since 2002 from the Korean Architecture Administration System (KASS) [44]. Next, we combined permit data, parcel spatial information, and parcel land identification number. Finally, we overlaid port hinterlands, coastal flood risk areas, and permits over spatial information. 
Table 2. Description of variables.

\begin{tabular}{|c|c|c|c|}
\hline Variables & Operational Definition & Expected Effect & Source \\
\hline \multicolumn{4}{|c|}{ Flood damage in coastal cities (Dependent variable) } \\
\hline Rain and storm damage & $\begin{array}{l}\text { The logarithm of the total damage value } \\
\text { caused by heavy rain and typhoon, in } \\
2010 \text { Korean won. }\end{array}$ & Dependent variable & $\begin{array}{l}\text { Yearbook of } \\
\text { Disaster [38] }\end{array}$ \\
\hline \multicolumn{4}{|l|}{ Meteorological factors } \\
\hline Daily precipitation & $\begin{array}{l}\text { The logarithm of the daily precipitation at } \\
\text { each weather bureau station. }\end{array}$ & + & KCDSS [40] \\
\hline City located on South Sea & $\begin{array}{l}\text { From Haenam-gun, Jeonnam to } \\
\text { Haeundae-gu, Busan. }\end{array}$ & + & $\begin{array}{l}\text { Basic Survey of } \\
\text { Coast [37] }\end{array}$ \\
\hline \multicolumn{4}{|l|}{ Vulnerable factors } \\
\hline Population over 65 & $\begin{array}{l}\text { The logarithm of the population } 65 \text { years } \\
\text { or older. }\end{array}$ & + & KOSIS [41] \\
\hline Local taxes & The logarithm of local taxes. & - & KOSIS [42] \\
\hline \multicolumn{4}{|l|}{ Exposure factors } \\
\hline Impervious area & $\begin{array}{l}\text { The logarithm of the area corresponding } \\
\text { to site, factory site, and roads in land } \\
\text { category. }\end{array}$ & + & KOSIS [43] \\
\hline $\begin{array}{l}\text { Urban development permits in } \\
\text { hinterland and in coastal flood } \\
\text { risk area }\end{array}$ & $\begin{array}{l}\text { Development permits occurring within } \\
1.5 \mathrm{~km} \text { of the port within the coastal flood } \\
\text { risk area. }\end{array}$ & + & KASS [44] \\
\hline
\end{tabular}

Note) KCDSS: Korean Climate Data Service System, KOSIS: Korean Statistical Information System, KASS: Korean Architecture Administration System.

\subsection{Descriptive Statistics}

Table 3 shows the descriptive statistics for the variables in this study. In the case of the dependent variable of damage, the average cost was US $\$ 3.99$ million ( 4.79 billion KRW, 1 USD $=1200 \mathrm{KRW}$ ). However, we identified this dependent variable to be zero in some cases. In the study period, 301 cases did not have a flood event every year. Statistics for flood damage in coastal cities for this study are not available for every year. In addition, when determining flood damage, it should be noted that in Korea the government collects flood damage data; however, this does not appear as damage unless a certain threshold of exposure is reached. Figure 3 shows that the total impervious area is continuously increasing. Development in port hinterlands and coastal flood risk areas changed over this period.

Table 3. Descriptive statistics.

\begin{tabular}{lcccc}
\hline \multicolumn{1}{c}{ Variables (Unit) } & Mean & Standard Deviation & Min & Max \\
\hline Flood damage (million USD) & 3.99 & 19.02 & 0.00 & 334.62 \\
Daily precipitation (mm) & 130.13 & 50.37 & 37.00 & 383.00 \\
Population over 65 (1000s) & 22.09 & 14.85 & 5.21 & 131.61 \\
Local taxes (million USD) & 153.12 & 192.15 & 8.05 & 1702.05 \\
Impervious areas (km²) & 32.61 & 20.54 & 2.22 & 130.84 \\
Urban development permits in hinterland & 13.49 & 29.45 & 0.00 & 246.00 \\
and in coastal flood risk area (1 permit) & & 25 of 58 & & \\
City located on South Seas (Dummy) & & & & \\
Note) 1 USD = 1,200 KRW & & & \\
\hline
\end{tabular}




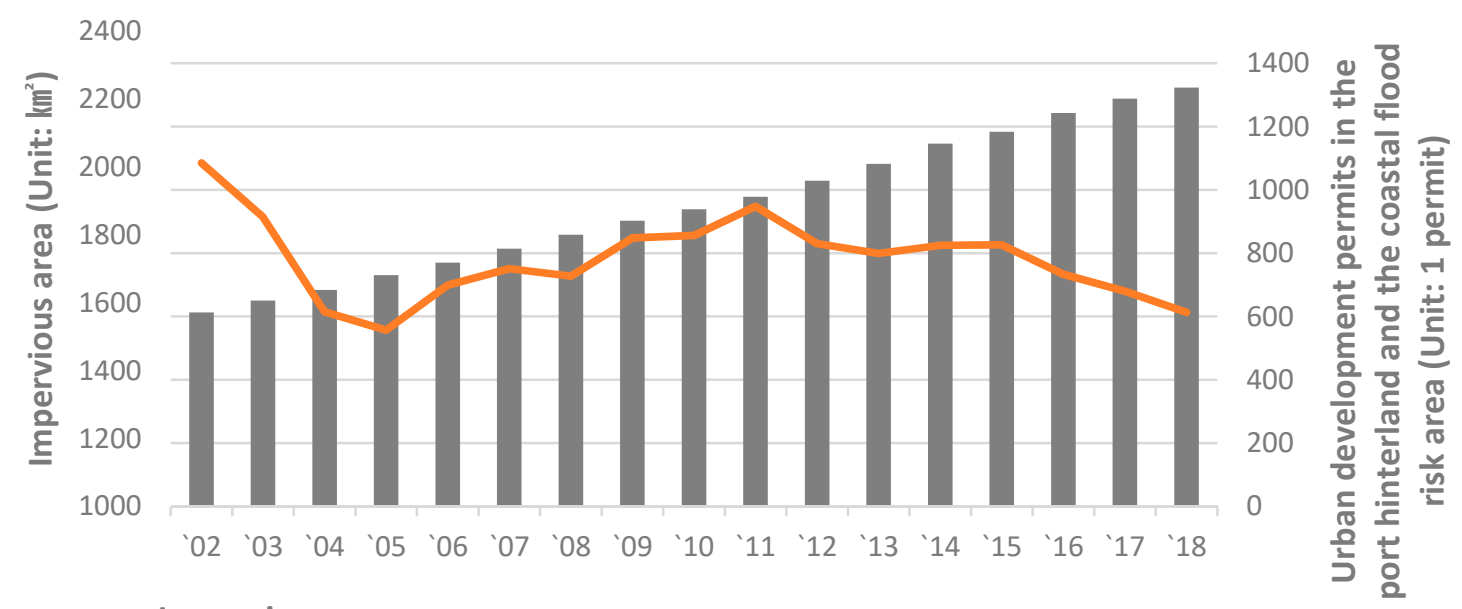

Impervious area

Urban development permits in the port hinterland and the coastal flood risk area

Figure 3. Trend of coastal city developments in case areas from 2002 to 2018.

\subsection{Analysis Methods}

We employed a panel data model. The advantage of the panel model lies in the fact that, as the number of observations used in the model increases, the degree of freedom of the model can be increased and efficiently estimated [45,46]. This helps to estimate the effect of the factor in disasters [47]. Furthermore, the panel model should be used with heteroscedasticity (Wald test) and autocorrelation (Wooldridge test) tests before estimation [48]. Heteroscedasticity and autocorrelation impact the consistency and the efficiency of estimators [45]. The Wald test detects the heteroscedasticity according to the group, and the Wooldridge test can indicate autocorrelation under general conditions $[49,50]$. Therefore, this study analyzed the heteroscedasticity and autocorrelation of the data and selected a panel generalized least square (GLS) model. GLS estimation considers assumptions relating to heteroscedasticity and autocorrelation. This is because GLS uses maximum likelihood to solve these assumptions. We can employ the random-effect or fixed-effect model based on ordinary least square (OLS) estimation, given that the data did not have heteroscedasticity and autocorrelation.

As shown in Table 4, the Wald test on heteroscedasticity was not significant, and the Wooldridge test on first-order autocorrelation was significant. Therefore, a panel GLS analysis was performed with regard to homoscedasticity and autocorrelation. We also considered the distribution of the dependent variables, and it was observed to be zero for 301 cases in the dataset. In addition, since a large amount of zero-flood damage was observed, panel GLS analysis underestimated the coefficients. The Tobit estimation overcame the underestimation due to the zero found for the dependent variables [51]. One advantage of using a Tobit estimation was that we were able to include "no flood damage cases" of observations which were flooded [52]. The panel Tobit estimation employed the Tobit estimation in panel data analysis. The panel Tobit estimation can solve heteroscedasticity and autocorrelation with maximum likelihood [53].

Table 4. Heteroscedasticity and autocorrelation test.

\begin{tabular}{cc}
\hline Heteroscedasticity (Wald test) & Autocorrelation (Wooldridge test) \\
\hline 70.62 & $4.347^{* *}$ \\
\hline & \\
&
\end{tabular}




\section{Results}

Table 5 depicts the results of analyzing the panel data from 2002 to 2018 . The panel analysis consisted of pooled OLS, the panel GLS, and the panel Tobit analysis. As a result of the pooled OLS analysis, the explanatory power of all variables was approximately $27.96 \%$, and the F-test value was 64.70 ( $p$-value < 0.01). Daily precipitation, local taxes, impervious areas, and urban development permits in the port hinterland and coastal flood risk areas were found to have significant effects. Among the significant variables, all variables except local taxes were positive. However, OLS estimators were not unbiased and consistent, based on Wald test and Wooldridge test results.

Table 5. Panel analysis.

\begin{tabular}{lccc}
\hline \multirow{2}{*}{ Variables } & Pooled OLS & Panel GLS & Panel Tobit \\
\cline { 2 - 4 } & Coefficient & Coefficient & Coefficient \\
\hline Daily precipitation & $8.2900^{* * *}$ & $8.4957^{* * *}$ & $11.5353^{* * *}$ \\
City located on South Seas & -0.0769 & -0.1649 & -0.3289 \\
Population over 65 & 0.0459 & -0.0440 & -0.2577 \\
Local taxes & $-0.7530^{* * *}$ & $-0.7510^{* * *}$ & $-0.9142^{* *}$ \\
Impervious areas & $1.1349^{* * *}$ & $1.1401^{* * *}$ & $1.5282^{* * *}$ \\
Urban development permits in & & & \\
hinterlands and in coastal & $0.0207^{* * *}$ & $0.0224^{* * *}$ & $0.0273^{* * *}$ \\
flood risk areas & & & $-54.8072^{* * *}$ \\
Constant & -37.0827 & $-37.2335^{* * *}$ & - \\
Adjusted R-square & 0.2796 & & $307.19^{* * *}$ \\
F-test & $64.70^{* * *}$ & - & 928 \\
Wald test(Chi-square) & - & $404.80^{* * *}$ & 301 \\
Number of observations & 928 & 928 & - \\
Censored observations & - & & - \\
\hline
\end{tabular}

Note 1$)^{* * *} p$-value $<0.01,{ }^{* *} p$-value $<0.05$. Note 2) OLS: Ordinary Least Square, GLS: Generalized Least Square.

In addition, the panel GLS analysis was conducted using panel data from 2002 to 2018. Analysis results revealed that the chi-square value of the Wald test was 404.80 ( $p$-value $<0.01$ ), which is considered suitable for the analysis model. The significant variables were daily precipitation, local taxes, impervious areas, and urban development permits in port hinterlands and coastal flood risk areas. Compared to OLS, the significance of variables were identical.

Finally, Tobit estimates were made for panel data from 2002 to 2018. The result of the likelihood ratio (LR) test on variance among panel subjects was statistically significant $(p$-value $<0.01)$ for the Tobit estimation. This means that the probability effect of the Tobit estimation was performed accordingly. The analysis revealed that the chi-square value of the Wald test was 307.19 ( $p$-value $<0.01$ ), and this was accepted as a suitable analysis model. Results indicated that the significant variables in the pooled OLS, such as daily precipitation, local taxes, impervious areas, and urban development permits in port hinterlands and the coastal flood risk areas, were significant.

In terms of the effects of the variables, south coast locations and populations over 65 decreased flood damage in case areas. Although their coefficients were not statistically significant, the reason for this effect was as follows: The reason for the negative location of the south coast can be seen as the characteristic of the south coast city. The south coast is located in the paths of hurricanes that occur every year [37]. However, south coast cities, such as those near the Gwangyang-si, Jeonnam, Joong-gu, and Gangseo-gu, Busan, have developed ports and industrial parks $[10,36]$. As a result, south coast cities have adapted to cope with the threat of natural disasters. The number of people over the age of 65 may not influence flood damage in case areas, statistically. Although previous research has indicated that populations aged 65 or older were vulnerable, this vulnerability relates to physical condition [25]. Furthermore, greater numbers of the elderly live in the city, due to urbanization and the phenomenon of an aging society, and the city has more resources to respond to floods than rural areas. We did not 
identify a significant relationship between economic damage and the elderly. The coefficients of these variables were not statistically significant; therefore, we could not consider their effect in case areas.

Table 6 compares the estimated results of the panel GLS and panel Tobit from 2002 to 2018, and it shows that the significant variables increased from the previously estimated coefficient value. In the case of the largest amount of daily rainfall, the coefficient was 8.4957 in the panel GLS but increased to 9.7509 in the panel Tobit estimation, an approximate 1.15-fold increase. Even in the case of urban development, for permits in coastal flood risk areas, the coefficient value increased by 1.03 times (from 0.0224 to 0.0231 ). This means that an increase in the number of urban development permits in port hinterlands and in coastal flood risk areas would increase flood damage by approximately $2 \%$. This result indicates that the coefficient is underestimated in the censored variables.

Table 6. Marginal effect of each variable.

\begin{tabular}{lccc}
\hline & Variables & Panel GLS & Panel Tobit \\
\hline Daily precipitation & 8.4957 & 9.7509 \\
City located in south coast & -0.1649 & -0.2778 \\
Population over 65 & -0.0440 & -0.2178 & -0.7727 \\
Local taxes & -0.7510 & 1.2918 \\
Impervious areas & 1.1401 & 0.0231 \\
Urban development permits in the port hinterland and the coastal flood risk area & 0.0224 & \\
\hline
\end{tabular}

Note 1) Shading represents significant variables in a regression analysis. Note 2) GLS: Generalized least squares.

When analyzing the trade-offs between development and safety, Burby [20] and Cutter et al. [21] used the case analysis of one region. They indicated that the significant effects of the conflict between development and safety were analyzed in relation to the actual flood damage. Using development variables in coastal cities, we found that exposure led to an increase in flood damage. Based on the conceptual model, the changes in coastal cities that have been affected by port development were shown to be correlated with flood damage in coastal cities. Furthermore, permits in port hinterlands and in coastal flood risk areas had a significant impact on flood damage.

Compared with the research conducted in Korea, the chi-square value of the model was different. According to Ha and Jung [23], the model fit value was 233.13 (chi-square value). This study found it to be 307.19. Statistically significant values implied that the model in this study was appropriate. This means that the coefficient values in the derived model are acceptable as explanatory results.

The results of the analysis were in line with previous studies, indicating that the number of development permits analyzed in previous studies and flood damage were related. In a previous study analyzing flood damage, Brody et al. [22] found that development permits in wetlands could increase flood damage and demonstrated that efforts to conserve wetlands were more effective than dams. Increases in impermeable areas also increased the amount of water that was unable to penetrate the surface, and flood damage has been correlated with increased urban development in risk areas. In particular, a 17-year panel analysis found that an increase in the number of urban development permits in coastal flood risk areas behind ports could increase flood damage by approximately $2 \%$. In light of this, when urban development permits were increased in coastal flood risk areas behind a port, the burden of exposure to flood damage also increased, and this would require more mitigation measures.

\section{Conclusions and Discussion}

This study analyzed how coastal city development could affect flood damage. Conceptualization on exposure in coastal cities integrated Burby's local government paradox [20] and Holye's port-city model [6]. In this process, spatial information on permits in coastal cities was used as a variable for panel analysis. We analyzed how much impervious area was developed in coastal cities and how many permits were issued in port hinterlands and coastal flood areas. To develop the port-city model for flood damage, we performed a panel analysis. Panel analyses were conducted for 58 coastal cities from 2002 to 2018, and estimates were made using panel Tobit estimation. This estimation overcame 
the challenges of underestimation. One difference from previous studies was that the higher the impervious area in coastal cities, the greater the flood damage. The statistically significant results for impervious areas were consistent with studies in Korea [23,47]. Therefore, it is necessary to increase pervious areas when proceeding with port and urban development in coastal cities.

These analyses could have implications for policy makers. First, port hinterland development in coastal flood areas should be considered in coastal cities. Consideration should be given to the development of coastal flood hazard areas behind ports. The paradox between development and safety has emerged in coastal cities. Burby [20] argued that a plan to manage the conflict between development and safety was important. The importance of planning has also been raised in Europe. According to STAR-FLOOD, which is an EU research project for flood risk governance, flood damage can be reduced in Europe when sectoral policy bodies come together to formulate urban planning [15]. Therefore, to reduce flood damage in coastal cities in Korea, a number of measures can be implemented. First, urban planning governance that includes ports should be established. Integrating governance with urban planning and port planning can help manage urban development near ports to appropriate levels. It can help minimize risky development by combining urban planning with port planning. Such governance can avoid the conflict between safety and development near ports. Even if governance is integrated, policy makers should find and share development information in risk areas. They should also formulate policies, such as restrictions, land acquisitions, setbacks, and so on. Moreover, if the decision to proceed with development is taken, impervious areas should be minimized. A low-impact development approach that minimizes impervious areas should be considered in urbanized areas. Environmental mitigation measures, such as detention, bio swale, and parks in paved areas, should also be undertaken. Coastal cities can minimize the conflict associated with the paradox of development in port hinterlands and coastal flood risk areas.

Second, the development effects in coastal cities should be internalized in the same manner that wetland permit fees were internalized [22,54]. This is because results indicated that development in port hinterlands and coastal flood areas has significant effects on communities. Accordingly, the planning agency should establish an appropriate development activity fee. The regulation and burden of development in risk areas make development less attractive to developers. Currently, in South Korea, the processing fee per container is supposed to be US\$12.70 (15,000 KRW). This fee taxes the devices and externalities of port activity, such as traffic congestions, road repairs, and poor air quality. Local governments, to ensure public safety, should impose fees on facilities that develop coastal flood risk areas behind ports, which induce risk development.

Further research is needed in the following areas. First, research on trend analysis and impact analysis of the trade-offs between development and safety should be conducted with different units of analysis. Future research requires analysis of disaster occurrence units, including watershed units and detailed spatial units, such as districts and parcels. Due to the limitation of the data on flood damage, this study analyzed data at the city level, but future studies should analyze more basic or smaller units of flood damage. Efforts should be made to identify the relationship between flood damage and urban development in port hinterlands. In addition, future research should examine the effect of the elderly population on damage. If conducted on a more basic level, research will be able to demonstrate whether the elderly suffer from floods and, if so, why. Second, future studies should investigate how risky developments were induced by ports in coastal cities, where climate change has a significant impact. A case study can explore how the local development paradox was increased [21]. Coastal city case studies should employ longer timeframes to find risk areas. In longer timeframes, properties such as hourly, daily, and monthly precipitation can be employed to predict flood events with accuracy through data-driven and statistical methods [55-59]. A case study with longer timeframes can also demonstrate how risky developments increase, and it can also predict such developments in port hinterlands. Third, we used variables related to development and risk. Future research should attempt to identify the effects of other infrastructure projects, such as electricity, water and sewerage, and roads. 
Such an approach could improve the quality of the dataset and enhance the accuracy of estimation methods, which should be enhanced with a statistical approach [2,4].

The presence of dangerous areas in coastal cities does not necessarily cause flood damage. Not all urban development has a significant effect. Depending on where development occurs, there may be a correlation with flood damage. The conflict between development and safety is one of the most challenging problems facing coastal cities, and flood damage may increase when development takes place in these areas.

Author Contributions: Conceptualization, H.P., R.P., J.J., H.S., Y.J., and S.Z.; methodology, H.P.; writing—original draft preparation, H.P.; writing-review and editing, J.J.; supervision, J.J.. All authors have read and agreed to the published version of the manuscript.

Funding: This research was supported by PNU-RENovation(2018-2019). This work is financially supported by Korea Ministry of Environment (MOE) as Graduate School specialized in Climate Change.

Acknowledgments: This research was supported by PNU-RENovation(2018-2019). This work is financially supported by Korea Ministry of Environment (MOE) as Graduate School specialized in Climate Change. This work is based on the Park's Ph.D. thesis [60].

Conflicts of Interest: The authors declare no conflict of interest.

\section{References}

1. Beatley, T. Planning for Coastal Resilience: Best Practices for Calamitous Times; Island Press: Washington, DC, USA, 2009.

2. Chau, K.W. Use of meta-Heuristic techniques in rainfall-Runoff modelling. Water 2017, 9, 6. [CrossRef]

3. Myronidis, D.; Stathis, D.; Sapountzis, M. Post-Evaluation of flood hazards induced by former artificial interventions along a coastal Mediterranean settlement. J. Hydrol. Eng. 2016, 21, 05016022. [CrossRef]

4. Myronidis, D.; Ioannou, K. Forecasting the urban expansion effects on the design storm hydrograph and sediment yield using artificial neural networks. Water 2019, 11, 31. [CrossRef]

5. Bird, J.H. The Major Seaports of the United Kingdom; Hutchinsonl: London, UK, 1963.

6. Hoyle, B. Global and local change on the port-City waterfront. Geogr. Rev. 2000, 90, 395-417. [CrossRef]

7. Hanson, S.; Nicholls, R.; Ranger, N.; Hallegatte, S.; Corfee-Morlot, J.; Herweijer, C.; Chateau, J.A. Global ranking of port cities with high exposure to climate extremes. Clim. Chang. 2011, 104, 89-111. [CrossRef]

8. Fredrickson, A. The California Coastal Act and ports: The unintended environmental justice implications of preserving California's coastline. Coast. Manag. 2013, 41, 258-271. [CrossRef]

9. Ramos, S. Planning for competitive port expansion on the US Eastern Seaboard: The case of the Savannah Harbor Expansion Project. J. Transp. Geogr. 2014, 36, 32-41. [CrossRef]

10. Song, D.; Lee, S. Port governance in Korea: Revisited. Res. Transp. Bus. Manag. 2017, 22, 27-37. [CrossRef]

11. Ziadah, R. Constructing a logistics space: Perspectives from the Gulf Cooperation Council. Environ. Plan. D Soc. Space 2018, 36, 666-682. [CrossRef]

12. Ng, A.; Becker, A.; Cahoon, S.; Chen, S.; Earl, P.; Yang, Z. (Eds.) Climate Change and Adaptation Planning for Ports; Routledge: Abingdon, UK, 2015.

13. Fenton, P. The role of port cities and transnational municipal networks in efforts to reduce greenhouse gas emissions on land and at sea from shipping-An assessment of the world ports climate initiative. Mar. Policy 2017, 75, 271-277. [CrossRef]

14. Aregall, M.G.; Bergqvist, R.; Monios, J.A. Global review of the hinterland dimension of green port strategies. Transp. Res. Part D Transp. Environ. 2018, 59, 23-34. [CrossRef]

15. Hegger, D.L.T.; Driessen, P.P.J.; Bakker, M.H.N. (Eds.) A View on More Resilient Flood Risk Governance: Key Conclusions of the STAR-FLOOD Project; STAR-FLOOD consortium: Utrecht, The Netherlands, 2016.

16. Berke, P. Natural-hazard reduction and sustainable development: A global assessment. J. Plan. Lit. 1995, 9, 370-382. [CrossRef]

17. Burby, R.; Beatley, T.; Berke, P.; Deyle, R.; French, S.; Godschalk, D.; Kaiser, E.; Kartez, J; May, P.; Olshansky, R.; et al. Unleashing the power of planning to create disaster-Resilient communities. J. Am. Plan. Assoc. 1999, 65, 247-258. [CrossRef] 
18. Godschalk, D. Urban hazard mitigation: Creating resilient cities. Nat. Hazards Rev. 2003, 4, $136-143$. [CrossRef]

19. Berke, P.; Stevens, M. Land use planning for climate adaptation: Theory and practice. J. Plan. Educ. Res. 2016, 36, 283-289. [CrossRef]

20. Burby, R. Hurricane Katrina and the paradoxes of government disaster policy: Bringing about wise governmental decisions for hazardous areas? Ann. Am. Acad. Political Soc. Sci. 2006, 604, 171-191. [CrossRef]

21. Cutter, S.; Emrich, C.; Gall, M.; Reeves, R. Flash flood risk and the paradox of urban development. Nat. Hazards Rev. 2017, 19, 05017005. [CrossRef]

22. Brody, S.D.; Zahran, S.; Maghelal, P.; Grover, H.; Highfield, W.E. The rising costs of floods: Examining the impact of planning and development decisions on property damage in Florida. J. Am. Plan. Assoc. 2007, 73, 330-345. [CrossRef]

23. Ha, G.J.; Jung, J.C. The impact of urbanization and precipitation on flood damage (in Korean). J. Korean Plan. Assoc. 2017, 52, 237-252. [CrossRef]

24. UNISDR (United nations Office for Disaster Risk Reduction). National Disaster Risk Assessment; UNISDR: Geneva, Switzerland, 2017. Available online: https://www.unisdr.org/files/globalplatform/ 591f213cf2fbe52828_wordsintoactionguideline.nationaldi.pdf (accessed on 13 February 2020).

25. Cutter, S.; Boruff, B.J.; Shirley, W.L. Social vulnerability to environmental hazards. Soc. Sci. Q. 2003, 84, 242-261. [CrossRef]

26. Seo, H.J.; Jung, J.C.; Lee, D.B. The impact of local financial capability on damage from natural disasters. J. Korean Soc. Hazard Mitig. 2018, 18, 381-389. [CrossRef]

27. Lee, D.B.; Jung, J.C. The growth of low-income population in floodplains: A case study of Austin, TX. KSCE J Civ Eng. 2014, 18, 683-693. [CrossRef]

28. Restemeyer, B.; Woltjer, J.; van den Brink, M. A strategy-Based framework for assessing the flood resilience of cities? A Hamburg case study. Plan. Theory Pract. 2015, 16, 45-62. [CrossRef]

29. Notteboom, T.; Rodrigue, J. Port regionalization: Towards a new phase in port development. Marit. Policy and Manag. 2005, 32, 297-313. [CrossRef]

30. United Nations Conference on Trade and Development. Port Performance-Linking Performance Indicators to Strategic Objectives. 2016. Available online: https://unctad.org/en/PublicationsLibrary/dtlkdb2016d1_en.pdf (accessed on 13 February 2020).

31. Becker, A.; Inoue, S.; Fischer, M.; Schwegler, B. Climate change impacts on international seaports: Knowledge, perceptions, and planning efforts among port administrators. Clim. Chang. 2012, 110, 5-29. [CrossRef]

32. Osthorst, W.; Manz, C. Types of cluster adaptation to climate change: Lessons from the port and logistics sector of Northwest Germany. Marit. Policy Manag. 2012, 39, 227-248. [CrossRef]

33. Helderop, E.; Grubesic, T. Social geomorphic, and climatic factors driving U.S. coastal city vulnerability to storm surge flooding. Ocean Coast. Manag. 2019, 181, 104902. [CrossRef]

34. Valente, S.; Veloso-Gomes, F. Coastal climate adaptation in port-Cities: Adaptation deficits, barriers, and challenges ahead. J. Env. Plan. Manag. 2020, 63, 389-414. [CrossRef]

35. Kantamaneni, K.; Gallagher, A.; Du, X. Assessing and mapping regional coastal vulnerability for port environments and coastal cities. J Coast. Conserv. 2019, 23, 59-70. [CrossRef]

36. Cho, G.W.; Lee, H.M.; Kim, T.Y.; Kang, J.E.; Tobuoka, T. National Assessment on Sea Level Rise Impact of Korean Coast in the Socioeconomic Context II (in Korean); Korea Environmental Institute: Seoul, Korea, 2012.

37. Ministry of Oceans and Fisheries. Basic Survey of Coast; MOF: Sejong, Korea, 2015. (In Korean)

38. Ministry of Interior and Safety. Yearbook of Disaster; MOIS: Sejong, Korea, 2017.

39. Kim, D.; Choi, W.; Shim, J. World natural hazards trend and type analysis. Water Future 2008, 41, 56-64. (In Korean)

40. Korean Climate Data Service System: Hourly Precipitation. 2019. Available online: https://data.kma.go.kr/ data/grnd/selectAwsRltmList.do?pgmNo=56 (accessed on 13 February 2020).

41. Korean Statistical Information Service: Population by Age Group. 2019. Available online: http://kosis.kr. (accessed on 13 February 2020).

42. Korean Statistical Information Service: Local Tax. 2019. Available online: http://kosis.kr. (accessed on 13 February 2020).

43. Korean Statistical Information Service: Land Area. 2019. Available online: http://kosis.kr. (accessed on 13 February 2020). 
44. Korean Architecture Administration System: Permit. 2019. Available online: http://eais.go.kr. (accessed on 13 February 2020).

45. Gujarati, D. Basic Econometrics; McGraw-Hill: New York, NY, USA, 2009.

46. Baltagi, B. Econometric Analysis of Panel Data; John Wiley \& Sons: New York, NY, USA, 1985.

47. Choi, C.I. Panel models about determining factors of urban flood damage. J. Korea Plan. Assoc. 2004, 39, 49-67. (In Korean)

48. Lee, H.Y.; Noh, S.C. Advanced Statistics Analysis; Moonwoosa: Seoul, Korea, 2012. (In Korean)

49. Baum, C. Residual diagnostics for cross-Section time series regression models. Stata J. 2001, 1, 101-104. [CrossRef]

50. Drukker, D. Testing for serial correlation in linear panel-Data models. Stata J. 2003, 3, 168-177. [CrossRef]

51. Tobin, J. Estimation of relationship for limited dependent variables. Encometrica 1958, 26, 24-36. [CrossRef]

52. Van Ootegem, L.; Van Herck, K.; Creten, T.; Verhofstadt, E.; Foresti, L.; Goudenhoofdt, E.; Reyniers, M.; Delobbe, L.; Murla Tuyls, D.; Willems, P. Exploring the potential of multi-Variate depth-damage and rainfall-Damage models. J. Flood Risk Manag. 2018, 11, S916-S929. [CrossRef]

53. Greene, W. Econometric Analysis; Pearson: New York, NY, USA, 2013.

54. Ha, G.; Jung, J.C. Applying conservation easement policy to river space to mitigate natural hazards in South Korea. Nat. Hazards 2019, 95, 805-822. [CrossRef]

55. Mosavi, A.; Ozturk, P.; Chau, K.W. Flood prediction using machine learning models: Literature review. Water 2018, 10, 1536. [CrossRef]

56. Wang, W.C.; Chau, K.W.; Xu, D.; Liu, D. The annual maximum flood peak discharge forecasting using Hermite projection pursuit regression with SSO and LS method. Water Res. Manag. 2017, 31, 461-477. [CrossRef]

57. Fotovatikhah, F.; Herrera, M.; Shamshirband, S.; Chau, K.W.; Aradabili, S.F.; Piran Md., J. Survey of computational intelligence as basis to big flood management: Challenges, research directions and future work. Eng. Appl. Comput. Fluid Mech. 2018, 12, 411-437. [CrossRef]

58. Yaseen, Z.M.; Sulaiman, S.O.; Deo, R.C.; Chau, K.W. An enhanced extreme learning machine model for river flow forecasting: State-Of-The-art, practical applications in water resource engineering area and future research direction. J. Hydrol. 2019, 569, 387-408. [CrossRef]

59. Shamshirband, S.; Hashemi, S.; Salimi, H.; Samadianfard, S.; Asadi, E.; Shadkani, S.; Kargar, K.; Masvi, A.; Nabipour, N.; Chau, K.W. Predicting standardized streamflow index for hydrological drought using machine learning models. Engin. Appl. Comput. Fluid Mech. 2020, 14, 339-350. [CrossRef]

60. Park, H.J. The Impact of Port Development on Inundation Damages in Coastal Cities. Ph.D. Thesis, Pusan National University, Busan, South Korea, August 2019. 